\title{
Pertimbangan Hakim Mahkamah Syar'iyah Langsa Terhadap Penggunaan Saksi De Auditu Dalam Perkara Perceraian
}

\author{
Yaser Amri, Azwir dan Arin Christiana \\ (Fakultas Syariah IAIN Langsa)
}

\begin{abstract}
Witness is a person who gives a statement in the court that qualify the certain conditions about an event or situation that he sees, hears and experiences himself as the evidence has occured an event or situation. Yet, How if the witnesses collected do not see or experience the incident directly but they only heard from someone else. In The positive legal terms, the witness is called testimonium de auditu, according to Islamic procedural law it is called syahadah al-istifadhah. In the process of how strength the legal evidence of the testimonium de auditu in a divorce case in the Langsa City Syar'iyah Court. Testimonium de auditu in civil procedural law, if it is according to positive law in article 171 HIR and article 1907 KUH. Civil of testimonium de auditu is not a tool of witness evidence, but it is used as a judge's judgment. But sometimes the exception of testimonium de auditu can be considered from the quality and strength of proof, the application depends on the case. In the perspective of Islamic law, the testimonium de auditu is categorized in the syahadah-istifada as a popular testimony. It means that the testimony delivered has become a public secret, a story in the community, or information in the community about the events that occurred.
\end{abstract}

Keywords: Judge Considerations, Witness De Autiu

\begin{abstract}
Abstrak: Saksi adalah orang yang memberikan keterangan di muka pengadilan dengan memenuhi syarat-syarat tertentu tentang suatu peristiwa atau keadaan yang ia lihat, dengar dan alami sendiri sebagai bukti kejadiannya peristiwa atau keadaan tersebut. Namun, bagaimana apabila saksi yang diajukan tidak melihat atau mengalami secara langsung peristiwa melainkan mendengar dari orang lain. Dalam istilah hukum positif saksi tersebut dinamakan testimonium de auditu, menurut hukum acara Islam disebut dengan syahadah al-istifadhah. Dalam proses beracara bagaimana kekuatan hukum alat bukti testimonium de auditu pada perkara perceraian di Mahkamah Syar'iyah Kota Langsa Bahwa testimonium de auditu dalam hukum acara perdata, jika menurut hukum positif khususnya pada pasal $171 \mathrm{HIR}$ dan pasal 1907 KUH Perdata testimonium de auditu bukan merupakan alat bukti saksi, melainkan dijadikan persangkaan Hakim. Namun adakalanya secara eksepsional testimonium de auditu dapat dipertimbangkan kualitas dan nilai kekuatan pembuktiannya, penerapannya tergantung kasus. Adapun mengenai perspektif hukum Islam testimonium de auditu dikategorikan dalam syahadah alistifadhah yaitu kesaksian yang populer. Artinya kesaksian yang disampaikan sudah menjadi rahasia umum, cerita dimasyarakat, atau informasi dimasyarakat tentang peristiwa yang terjadi.
\end{abstract}

Kata Kunci: Pertimbangan Hakim, Saksi De Autiu 


\section{PENDAHULUAN}

Saksi dalam Hukum Acara Perdata termasuk dalam hukum pembuktian. Pembuktian itu diperlukan oleh hakim untuk mencari kebenaran fakta dan peristiwa yang dijadikan dalil gugat oleh Penggugat dalam menuntut haknya. Jadi, pembuktian itu adalah untuk meyakinkan hakim tentang kebenaran dalil yang dikemukakan seseorang dalam suatu sengketa. Dalam hukum acara perdata Islam kesaksian disebut dengan "Syahādah" sedangkan dalam hukum acara positif disebut dengan testimonium. Idealnya saksi adalah orang yang secara langsung mendengar, melihat dan menyaksikan fakta/peristiwa yang sedang diperkarakan di pengadilan. Oleh karenanya, menjadi seorang saksi bukanlah perkara mudah, harus ada syarat dan ketentuan sebagai ukuran seorang dapat menjadi saksi. Selain itu pada kenyataannya, mencari seorang saksi yang dapat dipertanggungjawabkan kesaksiannya dalam arti orang yang melihat, mendengar dan menyaksikan secara langsung suatu peristiwa bukanlah hal mudah.

Oleh sebab itu, adakalanya saksi yang diajukan oleh pihak yang bersengketa adalah seorang yang tidak mengetahui atau menyaksikan suatu sengketa secara langsung atau lazim disebut testimonium de auditu. Hal ini tentunya berada diluar kategori kesaksian yang dibebankan dalam pasal 171 HIR dan pasal 1907 KUHPerdata, di mana kesaksian harus disertai keterangan tentang bagaimana saksi mengetahui kesaksiannya. ${ }^{114}$ Seorang saksi tidak boleh memberi keterangan-ketrangan yang berupa kesimpulan-kesimpulan, karena menarik kesimpulan-kesimpulan

114 Subekti, R, dan R. Tjitrosudibio, Kitab Undang-undang Hukum Perdata (KUH Perdata), (Jakarta: Pradnya Paramita, 2003). adalah wewernang hakim. ${ }^{115}$

Dasar hukum keterangan saksi menurut hukum islam disebutkan dalam Al-Qur'an firman Allah surat AlBaqarah ayat 283 sebagai berikut:

Jika kamu dalam perjalanan (dan bermu'amalah tidak secara tunai) sedang kamu tidak memperoleh seorang penulis, maka hendaklah ada barang tanggungan yang dipegang (oleh yang berpiutang). Akan tetapi jika sebagian kamu mempercayai sebagian yang lain, maka hendaklah yang dipercayai itu menunaikan amanatnya (hutangnya) dan hendaklah ia bertakwa kepada Allah Tuhannya; dan janganlah kamu (para saksi) menyembunyikan persaksian. Dan barangsiapa yang menyembunyikannya, maka sesungguhnya ia adalah orang yang berdosa hatinya; dan Allah Maha Mengetahui apa yang kamu kerjakan.

Pada hadis Nabi Saw riwayat alBaihaq dan al-Hakim bahwa Nabi Saw. Ditanya mengenai kesaksian, ia berkata kepada penanya:

(apakah) engkau melihat matahari ? ia menjawab: ya, maka Nabi bersabda : harus sepertinya (matahari) mempersaksikan atau lepaskan.

Firman Allah dan hadis Nabi diatas telah menjelaskan bahwa saksi harus mengalami secara langsung, bukan dari orang lain, pengetahuan seperti terangnya matahari tidak akan sempurna kecuali mengalami langsung. ${ }^{116}$

Alat bukti keterangan saksi

115 Lilik Mulyadi, Hukum Acara Perdata menurut Teori dan Praktik Peradilan Indonesia, (Jakarta: Djambatan, 1999), hal. 171

116 Aris Bintania, Hukum Acara Peradilan Agama dalam kerangka Fiqh al-Qadha, (Jakarta : Rajawali Pers, 2012), hal. 75-77

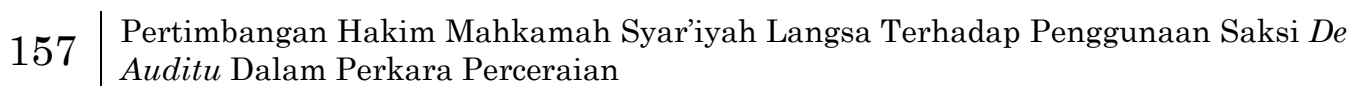


dalam Hukum Acara Perdata diatur dalam pasal $171 \mathrm{HIR}$ :

1) Tiap-tiap kesaksian harus berisi segala sebab pengetahuan.

2) Pendapat-pendapat atau persangkaan yang, istimewa, yang disusun dengan kata akal, bukan kesaksian.

Yang dimaksudkan "sebab pengetahuan" yaitu alasan-alasan pengetahuan, artinya dasar-dasar seorang saksi dapat mengatakan hal sesuatu dalam kesaksiannya. Ketentuan dalam pasal 171 ini ialah bahwa pada umumnya seorang saksi itu harus memberikan keterangan dari hal-hal yang ia lihat, dengar dan alami sendiri, dan bukanlah yang ia tahu dari keterangan orang lain. ${ }^{117}$

Permasalahan yang muncul yaitu apabila saksi yang diajukan atau yang ada tersebut tidak melihat atau mengalami secara langsung. Melainkan mendengar dari orang lain (testimonium de auditu), misalnya dalam perkara perceraian di Mahkamah Syar'iyyah Langsa, kesaksian seorang yang tidak mendengar langsung adanya pertengkaran. Apakah kesaksian tersebut dapat diterima di Mahkamah Syar'iyyah?

\section{METODOLOGI PENELITIAN}

Metode penelitian bermakna seperangkat pengetahuan tentang langkah-langkah sistematis dan logis dalam mencari data yang berkenaan dengan masalah tertentu untuk diolah, dianlisis, diambil kesimpulan dan selanjutnya dicarikan cara pemecahannya. 118 Metode penelitian yang digunakan dalam menyusun proposal ini sebagai berikut :

${ }^{117}$ www.hukumonline.com/pusatdata/downl oadfile/fl53195/parent/27228 hir, akses 10 Desember 2016

118 Soejono Soekanto, Pengantar Penelitiuan Hukum, (Jakarta: UI Press, 1986), hal. 21-22

\section{Jenis Penelitian}

Dalam penulisan proposal ini penulis menggunakan jenis penelitian lapangan (Field Research). Penelitian Lapangan (Field Research) yaitu penelitian yang dilakukan dengan cara mengumpulkan data-data dari lapangan yaitu dengan cara observasi. ${ }^{119}$ Dimana penelitian ini melakukan penelitian dengan cara mewawancarai langsung para hakim di Mahkamah Syar'iyyah Langsa.

\section{Lokasi Penelitian}

Lokasi penelitian di Mahkamah Syar'iyyah Langsa. Peneliti meneliti di Mahkamah Syar'iyyah Langsa dengan alasan pernah menyaksikan persidangan dimana yang menjadi saksi adalah saksi de auditu.

\section{Pendekatan Penelitian}

Pendekatan penelitian menggunakan pendekatan UndangUndang hukum perdata, buku hukum perdata, dan buku islam khususnya terfokus fiqh islam yang membahas tentang saksi de auditu.

\section{Sumber Data}

1. Data Primer, yaitu data yang diperoleh dari sumber asli yang memuat informasi. ${ }^{120}$ Sumber data primer ini adalah :

a. Hakim

karena fokus penelitian ini ingin mewawancarai hakim Mahkamah Syar'iyyah Langsa.

2. Data Sekunder, yaitu data yang diperoleh dari yang bukan asli dan memuat informasi. ${ }^{121}$ Adapun data

119 M. Nasir, Metode Penelitian, (Jakarta: Ghalia Indonesia, 1985), hal. 53

120 Sutrisno Hadi, Metodologi Research, (Yokyakarta: Lkis, 1999), hal. 9

121 Abudin Nata, Metodologi Studi Islam, cet-VIII ( Jakarta: PT Raja Grafindo Persada, 2003), hal. 126 
sekunder dalam penulisan proposal ini adalah :

a. Berbagai buku perdata dan buku hukum islam yang membahas tentang saksi de auditu

b. Berbagai artikel dan makalah tentang saksi de auditu

\section{Teknik Pengumpulan Data}

Pengumpulan data dalam penelitian ini dilakukan dengan cara sebagai berikut:

a. Metode Observasi

Observasi adalah teknik pengumpulan data yang dilakukan melalui suatu pengamatan, dengan disertai pencatatan-pencatatan

terhadap keadaan atau perilaku objek sasaran.

b. Metode Wawancara

Wawancara adalah teknik pengumpulan data melalui proses tanya jawab lisan yang berlangsung satu arah, artinya pertanyaan datang dari pihak yang mewawancarai dan jawaban diberikan oleh yang diwawancara.

Jenis wawancara yang digunakan adalah wawancara tidak berstruktur yaitu merupakan wawancara yang tidak menggunakan (mempersiapkan) daftar pertanyaan atau daftar isian sebagai pedoman selama proses wawancara.

c. Dokumentasi

Dokumentasi ialah teknik pengumpulan data dengan mempelajari catatan-catatan mengenai data pribadi responden. ${ }^{122}$ Dokumen yang

122 Abdurrahmat Fathoni, Metodologi Penelitian \& Teknik Penyusunan Skripsi, cet1, (Jakarta: PT Rineka Cipta, 2006), hal. 104112

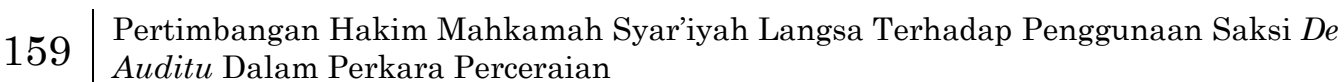

digunakan dapat berupa buku, putusan, peraturan-peraturan, karya ilmiah dalam bentuk skripsi dan lain sebagainya.

\section{Teknik Analisis Data}

Dalam menganalisis data penulis menggunakan metode deskriptif analisis ${ }^{123}$, yaitu suatu teknik analisis peristiwa yang terjadi pada saat sekarang dimana penulis menjabarkan data-data yang diperoleh dari hasil wawancara di lapangan kemudian menganalisanya dengan merujuk pada buku-buku yang berkaitan dengan permasalahan yang akan dijabar dalam penelitian ini, yang penulis dapatkan dari perpustakaan.

\section{PERTIMBANGAN HAKIM TERHADAP KETERANGAN SAKSI DE AUDITU}

Hakim dalam menangani suatu perkara diharuskan mendengar kedua belah pihak. Meskipun dalil dan bukti yang diajukan oleh salah satu pihak yang berperkara tidak memenuhi syarat formal dan syarat materiil, hakim tetap harus mendengarkan dalil tersebut, serta harus memeriksa bukti yang diajukan di depan persidangan.

Jika dalam suatu perkara salah satu pihak membawa alat bukti saksi yang keterangannya itu bersifat de auditu, hakim tetap harus memeriksa saksi tersebut dalam proses persidangan. Walaupun keterangan itu akan dipertimbangkan atau tidak dalam putusan, hal itu adalah kewenangan majelis hakim untuk menentukannya.

Dalam hal alat bukti keterangan Saksi De Auditu menurut bapak Salamat Nasution, S.H.I., M.A pada umumnya tidak dilampirkan dalam putusan, walaupun didalam

123 https://idtesis.com/metode-deskriptif, akses 10 Desember 2016 
persidangan Majelis Hakim berijtihad untuk membantu para pihak, tetapi dalam tulisannya tidak ditulis keterangan saksi de auditu. Karena jika dalam putusan mencantumkan bahwa saksi yang didatangkan dalam persidangan adalah saksi de auditu, perkara yag diadili pun susah untuk dikabulkan, sedangkan masyarakat awam tidak sepenuhnya mengerti tentang ilmu pembuktian, jadi majelis hakim hanya membantu masyarakat dalam mengadili perkara, sehingga dalam putusan jarang sekali tertulis bahwa keterangan saksi adalah keterangan saksi de auditu.

Beliau juga mengatakan jika ada saksi de auditu, itu namanya shahadah al istifadhah. Shahadah yaitu kesaksian sedangkan istifadah itu populer. Jadi shahadah al istifadah itu kesaksian yang populer. Artinya kesaksian yang disampaikan sudah menjadi rahasia umum, cerita dimasyarakat, atau informasi dimasyarakat bahwa kondisinya sudah seperti itu dan itu biasa kita lakukan hanya di isbat nikah. Kalau diperkara perceraian, katakanlah masalah pokok yaitu perselisihan pertengkaran, yang perlu dibuktikan pertama ada tidak berselisih bertengkar itu, secara real ada tidak bertengkar secara mulut, saling maki, kalau ini tidak didapatkan turunkan lagi, dengan pisah rumah, dicari lagi sumber pengetahuannya, jika saksi mengatakan ia sering berkunjung kerumah penggugat 4 atau 5 kali namun ia tidak pernah lagi melihat tergugat, nah ini sudah jadi sumber pengetahuan saksi, dengan alasan saksi sering kerumah penggugat, jadi itu sudah jadi faktor mengetahui sendiri, karena yurisprudensi Mahkamah Agung mengatakan pisah rumah itu merupakan indikator bahwa telah terjadi perselisihan pertengkaran dalam rumah tangga, dengan pisah rumahnyapun sudah bisa dijadikan bahwa gugatan penggugat itu dikabulkan, tetapi jatuhnya kepersangkaan hakim indikator, dengan saksi memberikan keterangan penggugat sudah pisah rumah, itu saja sudah bisa membuktikan rumah tangga mereka ada cekcok meskipun saksi tidak melihat langsung pertengkaran itu. ${ }^{124}$

Sedangkan menurut bapak Bukhari, S.H, beliau membenarkan bahwa hampir semua putusan tidak dilampirkan keterangan saksi yang bersifat de auditu dan majelis hakim pun tetap mendengarkan keterangan saksi tersebut, dengan alasan pertengkaran merupakan alasan yang dapat digunakan secara yuridis untuk menyembunyikan aib yang terjadi dalam kehidupan rumah tangga, sehingga banyak saksi yang hanya mengetahui adanya pertengkaran tersebut dari mulut ke mulut.

Beliau menjelaskan untuk menguatkan keterangan dari saksi, majelis hakim cukup menyimpulkan akibat dari perceraian tersebut, salah satu akibatnya yaitu pisah rumah, dengan saksi memberikan keterangan bahwa para pihak yang berperkara sudah tidak lagi tinggal serumah, dapat dipastikan sudah terjadi adanya perceraian dari kedua belah pihak. Alasan tersebut berdasarkan Yurisprudensi Mahkamah Agung Republik Indonesia Nomor: 379 K/AG/1995 tanggal 26 Maret 1997 yang mengandung abstraksi hukum "jika suami istri yang tidak berdiam serumah lagi dan tidak ada harapan untuk rukun kembali, maka rumah tangga tersebut telah terbukti retak dan pecah" serta Nomor 237 K/AG/1998 tanggal 17 Maret 1999 yang menyatakan bahwa cekcok, hidup pisah, tidak dalam satu tempat kediaman bersama dengan pihak lain,

\footnotetext{
${ }^{124}$ Wawancara Salamat Nasution (Hakim Mahkamah Syar'iyah Kota Langsa), pada tanggal 18 Desember 2017.
} 
merupakan fakta yang cukup sesuai alasan perceraian berdasarkan pasal 19 huruf (f) Peraturan Pemerintah nomor 9 Tahun 1975. Jadi dengan keterangan saksi bahwa para pihak sudah tidak serumah lagi dan juga sering terjadi cekcok terus-menerus, maka keterangan saksi tersebut meskipun keterangan yang bersifat de auditu tetapi tetap dijadikan pertimbangan hakim. ${ }^{125}$

Terkait dengan saksi atau keterangan saksi dikenal adanya istilah Testimonium de Auditu. Testimonium de auditu memiliki arti bahwa keterangan yang diberikan saksi bukanlah keterangan yang asalnya dari peristiwa/kejadian yang didengar, dilihat atau dialami sendiri oleh saksi tersebut, namun merupakan keterangan yang diperoleh saksi dari orang lain.

Berdasarkan pasal 16 (1) UU No. 14 Tahun 1970 jo. UU No. 4 Tahun 2004 tentang pokok-pokok kekuasaan kehakiman. Pengadilan (hakim) tidak boleh menolak untuk memeriksa dan memutus perkara yang diajukan dengan dalil bahwa hakim tidak ada atau kurang jelas, melainkan wajib memeriksa memutusnya.

Hakim sebagai organ pengadilan dianggap memahami hukum, pencari keadilan datang kepadanya untuk mohon keadilan. Andaikata ia tidak menemukan hukum tertulis, ia wajib menggali hukum tidak tertulis untuk memutuskan perkara berdasarkan hukum sebagai orang yang bijaksana dan bertanggung jawab penuh kepada Tuhan YME, diri sendiri, masyarakat, bangsa dan negara.

Pembuktian merupakan bagian yang sangat penting dalam proses penyelesaian suatu perkara yang sedang diperiksa dalam persidangan oleh majelis hakim. Dengan

\begin{tabular}{l}
\hline 125 Wawancara Bukhari (Hakim \\
Mahkamah Syar'iyah Kota Langsa), pada \\
tanggal 11 Januari 2018.
\end{tabular}

pembuktian ini diharapkan dapat dicapai suatu kebenaran yang sesungguhnya terhadap masalah yang menjadi sengketa diantara pihak, sehingga majelis hakim dapat menggali dan menyelesaikan sengketa itu dengan benar, adil dan sesuai menurut hukum islam.

Dalam hal menimbang nilai kesaksian, Hakim harus memperhatikan dengan seksama mengenai kesesuaian atau kecocokan antara keterangan para saksi, kesesuaian kesaksian dengan apa yang diketahui dari alat bukti lain atau dari keterangan-keterangan lainnya atau dengan kelogisan. Juga perlu diperhatikan segi lainnya yang lebih meyakinkan, seperti cara saksi bersikap dan berbicara di depan sidang, cara hidup dan lingkungan kehidupan seharihari, kedudukan saksi di tengah masyarakatnya dan lain sebagainya. Hal semacam ini sulit didetilkan dan sepenuhnya diserahkan kepada intelegensia Hakim sebagai pertanggung-jawaban kepada Tuhan dan negara. ${ }^{126}$

Berdasarkan pasal 171 HIR, pasal 1970 KUH Perdata, keterangan yang diberikan harus berdasarkan sumber pengetahuan yang jelas, dan sumber pengetahuan yang dibenarkan hukum harus merupakan pengetahuan, penglihatan, atau pendengaran yang bersifat langsung dari peristiwa atau kejadian yang berhubungan dengan pokok perkara yang disengketakan para pihak. Adapun istilah Testimonium De Auditu adalah keterangan karena mendengar dari orang lain yang disebut juga kesaksian tidak langsung.

Dalam hukum acara Islam, testimonium de auditu biasa disebut dengan Istilah Syahādah al Istifādah. Syahādah diartikan yakni kesaksian, dan Istifādah menurut bahasa ialah

$$
162
$$

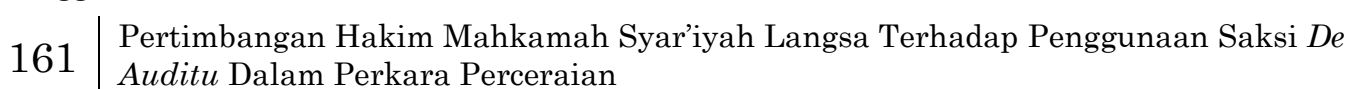


tersebar atau tersiar luas. Secara istilah ialah kesaksian dari orang yang tidak mengetahui secara langsung, tidak mengalami dan mendengar sendiri dengan terjadinya perbuatan hukum. Oleh karenanya dapat disimpulkan bahwa Syahādah al istifādah adalah kesaksian dari pihak ketiga dengan berdasar pada cerita orang lain, yang berita atau cerita tersebut sudah tersebar atau tersiar luas.

Seorang saksi harus melihat, mendengar atau mengalami sendiri peristiwa yang menjadi pokok sengketa. Bagi orang yang buta tetapi tidak tuli dapat memberikan kesaksian atas apa yang didengarnya. Bagi orang tuli tetapi tidak buta dapat memberikan kesaksian atas apa yang dilihatnya, bagi orang yang tuli tetapi bisu dapat memberikan kesaksian atas apa yang dilihatnya melalui tulisan. Sedangkan orang yang buta dan tuli dilarang memberikan kesaksian.

Saksi de auditu (Istifādah), khusus dalam hukum peradilan Islam lebih banyak digunakan dalam bentuk perkara yang bersifat perkara permohonan (Voluntair), sedangkan dalam bentuk perkara gugatan (contentious) tidak begitu banyak. Hampir semua kasus di pengadilan agama dalam perkara contentiousa pembuktiannya sudah didahului oleh alat bukti lain. Misalnya saksi seorang yang mengetahui dan mengalami langsung suatu peristiwa, baru kemudian didukung oleh beberapa orang saksi de auditu, atau alat bukti lain yang sudah ada misalnya pengakuan, kemudian diperkuat oleh beberapa saksi de auditu.

Dan Yahya Harahap sendiri berpendapat tidak begitu penting untuk memperdebatkan apakah testimonium de auditu dapat diakui atau tidak sebagai alat bukti, dan bukan saatnya lagi secara otomatis menolak dan mengatakannya tidak sah sebagai alat bukti. Dapat diterima dulu baru mempertimbangkan apakah ada eksepsional untuk menerimanya. Jika ada baru mempertimbangkan sejauh mana kualitas dan nilai pembuktian yang melekat pada keterangan saksi de auditu tersebut.

Setelah penulis telusuri pada Mahkamah Syar'iyah Kota Langsa penulis tidak menemui putusan yang bersifat testimonium de auditu pada perkara percereraian. Hal ini disebabkan karena dalam berita acara persidangan tidak dicantumkan jika adanya kesaksian yang bersifat testimonium de auditu. Pendapat ini diungkapkan oleh bapak Salamat Nasution, S.H.I., M.A, beliau menjelaskan "kesaksian yang bersifat testimonium de auditu pada umumnya tidak dilampirkan dalam putusan, walaupun didalam persidangan terdapat adanya saksi yang bersifat testimonium de auditu akan tetapi dalam putusan tidak ditulis keterangan saksi de auditu. Karena jika dalam putusan mencantumkan bahwa saksi yang didatangkan dalam persidangan adalah saksi de auditu, perkara yag diadili pun susah untuk dikabulkan, sedangkan masyarakat awam tidak sepenuhnya mengerti tentang ilmu pembuktian, jadi majelis hakim hanya membantu masyarakat dalam mengadili perkara, sehingga dalam putusan jarang sekali tertulis bahwa keterangan saksi adalah keterangan saksi de auditu"

Beliau juga mengatakan saksi de auditu tidak sertamerta dikesampingkan, tetap juga diterima untuk melengkapi bukti petunjuk dan persangkaan, tapi tidak bisa berdiri sendiri untuk mengendali suatu perkara yang sifatnya de auditu.

Kemudian menurut bapak Bukhari, S.H, beliau juga membenarkan bahwa hampir semua putusan tidak dilampirkan keterangan saksi yang bersifat de auditu dan 
majelis hakim pun tetap mendengarkan keterangan saksi tersebut, dengan alasan majelis hakim cukup menyimpulkan akibat dari perceraian tersebut, salah satu akibatnya yaitu pisah rumah.

Dari penjelasan diatas, pada prinsipnya testimonium de auditu tidak dapat diterima sebagai alat bukti. Hal ini sangat bergantung pada kasus perkasus. Apakah ada alasan yang kuat untuk mempercayai kebenaran dari saksi de auditu. Jadi paling tidak keterangan saksi de auditu dapat dipakai sebagai petunjuk.

Hakim sebenarnya harus mempertimbangkan hal-hal lebih banyak yang ada sangkut pautnya dengan melihat kasus perkasus. Oleh karena itu penilaiannya diserahkan pada pandangan hakim terhadap alat pembuktian saksi. Jadi dalam pandangan modern persaksian testimonium de auditu sah-sah saja untuk dipergunakan sebagai dasar untuk memutus suatu perkara, pendapat ini memberi kebebasan kepada hakim yang seluas-luasnya dalam hal menilai testimonium de auditu. Jika menurut hakim yang menyidangkannya ternyata keterangan saksi tersebut cukup reasonable (beralasan), maka keterangan saksi itu dapat diakui sebagai alat bukti tidak langsung, yakni lewat alat bukti petunjuk.

\section{PENUTUP}

Berdasarkan pembahasan yang telah diuraikan maka dapat disimpulkan bahwa kesaksian de auditu tidak dapat dijadikan alat bukti langsung, akan tetapi ia masuk dalam alat bukti tidak langsung. Kesaksian de auditu yang dikategorikan dalam persangkaan hakim hanya digunakan untuk melengkapi keterangan saksi yang memenuhi syarat materiil atau alat bukti lain. Dengan diterimanya melalui alasan eksepsional yang kemudian dikonstruksi sebagai bahan persangkaan. Dimana bukti persangkaan ini menyimpulkan terbuktinya suatu fakta dan peristiwa. Mahkamah Syar'iyah Kota Langsa tidak menutup kemungkinan bahwa kesaksian de auditu dapat digunakan dalam memutus dan mengadili perkara namun hal ini dikembalikan kepada hakim didasarkan kasus per kasus. 


\section{DAFTAR PUSTAKA}

A. Rasyid, Roihan. Hukum Acara Peradilan Agama, Jakarta : PT. RajaGrafindo Persada, 2007.

Bintania, Aris. Hukum Acara Peradilan Agama dalam kerangka Fiqh al-Qadha, Jakarta: Rajawali Pers, 2012.

Fathoni, Abdurrahmat. Metodologi Penelitian \& Teknik Penyusunan Skripsi, cet-1. Jakarta: PT Rineka Cipta, 2006.

Fauzan, M. Pokok-pokok Hukum Acara Perdata Peradilan Agama dan Mahkamah Syari'iyah Di Indonesia, cet- III, Jakarta : Kencana, 2007.

Hadi, Sutrisno. Metodologi Research, Yokyakarta: Lkis, 1999.

Harahap, Yahya. Hukum Acara Perdata, cet- XI, Jakarta: Sinar Grafika, 2011.

Nasir, M. Metode Penelitian, Jakarta: Ghalia Indonesia, 1985.

Nata, Abudin. Metodologi Studi Islam, cet-VIII. Jakarta: PT Raja Grafindo Persada, 2003.

Riza, Muhammad Fuad. Kekuatan Alat Bukti Testimonium De Auditu Dalam Perkara Perceraian Di Pengadilan Agama (Studi Perkara Perceraian di Pengadilan Agama Salatiga), 2013.

Soekanto, Soejono. Pengantar Penelitiuan Hukum, Jakarta: UI Press, 1986.

Supramono, Gatot. Hukum Pembuktian Di Peradilan Agama, cet-1, Bandung : Penerbit Alumni, 1993. 